\title{
PENGATURAN GARIS PANGKAL TERHADAP PERUBAHAN GARIS PANTAI DALAM UNITED NATIONS CONVENTION ON THE LAW OF THE SEA
}

\author{
Pinastika Prajna Paramita \\ Fakultas Hukum Universitas Islam Malang \\ Jl. MT Haryono, Nomor 193, Lowokwaru, Kota Malang 65144 \\ Telephone: 0341 - 581613 ext. 128, Fax: 0341 - 552249 \\ Email: pinastika.pp@unisma.ac.id
}

\begin{abstract}
This paper describes climate change that has an impact on sea boundaries for coastal countries. Physical impact significantly seen on the rising of sea levels due to the melting of polar's ice. As a result, the shifting of coastline of a coastal country cannot be avoided. The shifting of the coastline indicates a change on sea baseline which indicates as a starting point to measure the width of territorial sea of a coastal country. If the baseline of a country shifts due to rising sea levels, then the territorial sea and maritime zone of a country can also change. The international instrument on the Law of the Sea (UNCLOS 1982) has not provided clear guidance. On the other hand, changes in the sea baseline of a country can threaten the existence of coastal countries so that they can change the international maritime boundaries that have been recognized by all countries in the world. Alternative solutions to these problems are publication of baseline charts of every coastal countries; additional protocols to UNCLOS 1982; and conducting a bilateral or regional agreements between coastal country with adjacent coastline.
\end{abstract}

Keywords: Climate Change, Baseline, UNCLOS 1982, Teritorial sea

\begin{abstract}
ABSTRAK
Tulisan ini menjelaskan tentang perubahan iklim yang berdampak terhadap permasalahan batas-batas wilayah laut bagi negara pantai. Dampak fisik yang signifikan adalah meningkatnya permukaan air laut akibat mencairnya lapisan es di kutub-kutub bumi. Akibatnya, pergeseran garis pesisir pantai suatu negara pantai tidak dapat dihindari. Pergeseran garis pesisir pantai menandakan adanya perubahan pada garis pangkal laut yang berfungsi sebagai titik tolak diukurnya lebar laut teritorial suatu negara pantai. Apabila garis pangkal suatu negara bergeser akibat meningkatnya permukaan air laut, maka laut teritorial dan zona maritim suatu negara dapat pula berubah. Instrumen internasional tentang Hukum Laut (UNCLOS 1982) belum memberikan panduan yang jelas. Disisi lain adanya perubahan pada garis pangkal laut suatu negara dapat mengancam keberadaan negara-negara pantai sehingga dapat merubah batas-batas maritim internasional yang sudah diakui oleh semua negara di dunia. Alternatif solusi bagi permasalahan tersebut adalah publikasi bagan garis pangkal dari semua negara-negara pantai; protokol tambahan terhadap UNCLOS 1982 dan mengadakan perundingan bilateral atau regional untuk negara-negara pantai yang berdekatan.
\end{abstract}

Kata Kunci: Perubahan Iklim, Garis Pangkal, UNCLOS 1982, Laut Teritorial 


\section{PENDAHULUAN}

Laut telah menjadi bagian yang signifikan bagi kehidupan manusia. Hampir dua pertiga dari bumi ditutupi dengan lautan. Namun, dengan bertambahnya usia bumi, berbagai permasalahan terkait dengan keberlangsungan bumi pun terus bermunculan. Salah satu permasalahan yang paling penting dan membutuhkan resolusi segera adalah permasalahan terkait perubahan iklim. Perubahan iklim merupakan suatu fenomena universal yang mempengaruhi semua aspek kehidupan terutama terhadap manusia dan lingkungannya, termasuk di dalamnya adalah laut itu sendiri.

Panel Antar-Pemerintah tentang Perubahan Iklim (International Panel on Climate Change atau selanjutnya disebut IPCC) memberikan sebuah tinjauan penelitian mengenai perubahan iklim, dimana perkembangan perubahan iklim ini membawa pengaruh yang luas terutama pada enam sektor yaitu naiknya permukaan air laut dan pengaruh pesisir, pengasaman laut, ekosistem dan keanekaragaman hayati, sumber daya perairan dan penggurunan, pertanian dan pertahanan pangan, serta kesehatan manusia. ${ }^{1}$ Lebih lanjut lagi dijabarkan bahwa dengan naiknya permukaan air laut membawa dampak bagi komunitas manusia, dimana terdapat 63-102 juta jiwa akan terkena banjir dan tambahan 5-20\% dari lahan basah pesisir akan hilang. ${ }^{2}$

Meningkatnya permukaan air laut membawa dampak bagi pengaturan kedaulatan teritorial suatu negara, terutama bagi negara pantai. Negara-negara pantai, termasuk negara-negara yang ada di Asia Tenggara terutama Indonesia, merupakan wilayah yang dapat terkena dampak paling besar dengan naiknya permukaan air laut. ${ }^{3}$ Peristiwa ini mempengaruhi pengaturan suatu negara pantai terhadap batas-batas maritimnya, terutama perubahan fisik yang terjadi di garis pantai. Dengan naiknya permukaan air laut dapat mempengaruhi adanya perubahan dalam menentukan laut teritorial suatu negara pantai, khususnya titik dimana laut teritorial suatu negara pantai itu diukur. Peristiwa ini mengancam berkurangnya wilayah teritorial suatu negara akibat adanya kenaikan permukaan air laut karena perubahan iklim.

Mengenai upaya pengaturan kodifikasi hukum internasional, termasuk di dalamnya mengenai hukum laut mulai dilakukan sejak 1924 ditandai dengan adanya pembentukan Komisi Hukum Internasional (International Law Commission selanjutnya disebut ILC)

\footnotetext{
${ }^{1}$ Gosling, S.N.; Warren, R.; Arnell, N.W; Good,P. ; Caesar, J.; Bernie, D.; ... Smith, S.M. (2011, Agustus), A review of recent developments in climate change science. Part II: The global-scale impacts of climate change, Progress of Physical Geography, Vol.35, Iss.4, Hlm. 445

${ }^{2}$ Ibid. hlm 446

${ }^{3}$ Ibid.
} 
di bawah naungan Perserikatan BangsaBangsa (PBB). Pada tahun 1956, ILC atas permintaan Majelis Umum PBB menghasilkan laporan yang mencakup sebagian besar aspek hukum laut di bawah Konferensi PBB tentang Hukum Laut yang pertama (United Nations Conference on the Law of the Sea, yang selanjutnya disebut UNCLOS $)^{4}$. Namun, sayangnya UNCLOS I ini tidak dapat menjelaskan luasnya laut territorial suatu negara, sehingga pada tahun 1960 diadakan konferensi kedua yang menghasilkan UNCLOS II untuk membahas permasalahan laut teritorial, namun gagal. Pada konferensi ketiga diadakan sesi pertamanya pada tahun 1973 sampai pada akhirnya berhasil mengadopsi menjadi suatu konvensi pada tahun 1982. ${ }^{5}$ Konferensi ketiga inilah yang disebut sebagai UNCLOS III, yang menjadi payung hukum internasional mengenai wilayah lautan yang dapat diterima oleh semua pihak dan berlaku sampai saat ini. Pada tanggal 10 Desember 1982, UNCLOS III (atau dapat disebut dengan UNCLOS 1982) terbuka untuk pengesahan bagi negara-negara selama jangka waktu 2 tahun $^{6}$ and baru-baru ini sudah ada $167^{7}$ atau kurang lebih 3/5 dari semua negara di dunia telah meratifikasi konvensi ini.

Dengan adanya fenomena perubahan iklim ini menimbulkan problem dan tantangan baru dalam struktur hukum internasional yang telah ada tentang lautan yaitu bagaimana pengaturan garis pangkal pada UNCLOS 1982 dimana dengan adanya fenomena perubahan iklim tersebut, dapat menyebabkan perubahan penentuan titik garis pangkal diukur, dan untuk mengukur luasnya laut teritorial suatu negara pantai?

\section{PEMBAHASAN}

\section{Ketentuan UNCLOS 1982 Tentang Penentuan Garis Pangkal}

Fungsi dari garis pangkal laut sangat diperlukan untuk menetapkan batas mana suatu garis pantai yang diukur dari zona terluarnya tersebut dapat diukur, ${ }^{8}$ sehingga keberadaan titik dimana garis pangkal ini diukur akan menjadi mutlak keberadaannya bagi setiap negara pantai. Selain untuk mengukur batas laut teritorial suatu negara pantai, garis pangkal juga berfungsi untuk menentukan batas antara perairan dalam, ${ }^{9}$ dimana negara pantai tersebut dapat

\footnotetext{
${ }^{4}$ Lowe, A.V.; Churchill, R.R. (1999), The Law of the Sea ( $3^{\text {rd }}$ eds), Manchester: Manchester University Press, Hlm. 15.

${ }^{5}$ Ibid. hlm. 16.

${ }^{6}$ Ibid. Hlm. 19.

${ }^{7}$ United Nations Division for Ocean Affairs and the Law of the Sea, (2015), Chronological lists of ratification of, accessions and successions to the Convention and the related Agreements, diakses pada April, 28, 2015 dari http://www.un.org/Depts/los/reference_files/chronological_lists_of_ratifications.htm

${ }^{8}$ Lowe, Op. Cit. 31.

${ }^{9}$ Ibid.
} 
menjalankan kedaulatan penuh $^{10}$ dalam batas laut teritorialnya. Dengan adanya batas garis pangkal laut, negara pantai dapat menetapkan luas laut teritorialnya yang diukur hingga titik batas yang tidak melebihi 12 mil laut. ${ }^{11}$ Sementara itu, setiap negara memiliki hak untuk menentukan batas terluar dari laut teritorial negara tersebut dari garis setiap titik yang berada pada jarak terdekat dari garis dasar, sama dengan luasnya laut teritorial.

Lautan dan sumber daya alam yang terkandung di dalamnya memiliki kekayaan yang dapat menarik perhatian setiap negara yang berkepentingan. Oleh sebab itu, untuk menghindari adanya sengketa antar negara mengenai hal ini, setiap negara pantai harus mempublikasikan peta atau daftar koordinat geografisnya dari suatu skala atau skala yang memadai, untuk memastikan posisi negara tersebut; serta wajib memberikan salinan dari setiap peta atau daftar koordinat ke Sekretaris Jenderal PBB. ${ }^{12}$ Peta atau daftar koordinat geografis ini memuat batas garis pangkal laut dengan laut teritorialnya, termasuk didalamnya terdiri dari garis pangkal lurus (straight baseline), mulut sungai, teluk dan perbatasan laut teritorial antar negara dengan wilayah pantai yang bersebrangan atau berdekatan. ${ }^{13}$ Ketentuan ini dapat juga diterapkan dalam Zona Ekonomi Eksklusif (ZEE) dimana zona ini tidak lebih dari 200 mil laut dari garis pangkal dimana laut teritorial itu diukur. ${ }^{14}$ Penggambaran baseline juga dapat berdampak pada luasnya wilayah laut bebas dan juga penetapan batas maritim antar negara-negara dengan pantai yang berseberangan atau berdekatan. Dengan adanya aturan ini, kesalahpahaman antar negara tentang laut teritorial seuatu negara pantai dapat terselesaikan dan sengketa internasional dapat dihindari.

Kantor Urusan Kelautan PBB (Office for Ocean Affairs from the United Nations) mendifinisikan cara penetapan garis pangkal laut yang berdasarkan pada UNCLOS 1982. Terdapat tiga cara untuk menetapkan garis pangkal laut, dimana luas teritorial, zona tambahan, zona ekonomi eksklusif, serta dalam beberapa kasus tertentu meliputi landas kontinen, yang harus diukur. Langkah-langkahnya adalah:

a. Garis pangkal biasa (normal baseline) yang digunakan untuk mengukur luasnya laut teritorial adalah dengan garis permukaan air rendah (low water line) sepanjang pantai yang ditandai pada grafik skala besar, yang diakui

\footnotetext{
${ }^{10}$ Pasal 2 UNCLOS 1982.

${ }^{11}$ Pasal 3 UNCLOS 1982.

12 Pasal 16 UNCLOS 1982.

13 Ibid.

${ }^{14}$ Pasal 57 UNCLOS 1982.
} 
secara resmi oleh negara pantai. ${ }^{15}$ Selain itu, dalam kasus pulau-pulau yang memiliki garis bawah laut dari terumbu dapat digunakan sebagai garis pangkal. ${ }^{16}$ Konvensi ini juga mengindikasikan suatu kondisi dimana garis permukaan air rendah dalam elevasi tertentu dapat digunakan sebagai garis pangkal untuk mengukur laut teritorial. ${ }^{17}$

b. Garis pangkal lurus dapat diterapkan dalam kondisi di mana garis pantai menjorok ke dalam dan memotong, atau jika ada pinggiran pulau di sepanjang pantai di sekitarnya; dan dengan adanya delta dan kondisi alam lainnya garis pantai sangat tidak stabil, maka negara pantai dapat, dalam kondisi tertentu tertentu, menarik garis pangkal lurus dari mana luas laut teritorial diukur. Garis pangkal lurus tidak boleh ditarik ke dan dari elevasi rendah, kecuali mercusuar atau instalasi serupa yang berada di atas permukaan laut secara permanen telah dibangun di atasnya, atau kecuali misalnya ketika penggambaran garis pangkal menuju dan dari elevasi tertentu telah menerima pengakuan internasional secara umum. ${ }^{18}$

\footnotetext{
15 Pasal 5 UNCLOS 1982.

${ }^{16}$ Pasal 6, UNCLOS 1982.

${ }^{17}$ Pasal 13 UNCLOS 1982.

18 Pasal 7 UNCLOS 1982.

${ }^{19}$ Pasal 9, 10 UNCLOS 1982.
}

c. Garis pangkal dengan keadaan spesifik lokal tertentu seperti mulut sungai, teluk, pelabuhan atau pangkal laut. Konvensi ini memperbolehkan negara pantai untuk menentukan suatu garis lurus dengan mulut sungai yang langsung mengalir ke arah lautan and teluk tertentu, yang memenuhi serangkaian persyaratan. ${ }^{19}$ Selain itu, konvensi ini juga memperbolehkan penarikan garis pangkal lurus dalam kasus negara kepulauan sebagaimana diatur dalam pasal 47.

Dari cara-cara penentuan garis pangkal diatas, UNCLOS 1982 menunjukkan bahwa tidak ada pengeksklusifan bagi negara pantai untuk menentukanan cara penarikan garis pangkal lautan sebagaimana didasarkan pada Pasal 14 UNCLOS 1982, yaitu negara pantai dapat menentukan garis pangkal lautannya secara bergantian berdasarkan salah satu cara penarikan garis pangkal yang telah dijabarkan dalam UNCLOS 1982, sesuai dengan kondisi negara pantai masingmasing. Oleh karena itu, Negara-negara pantai memiliki kewenangannya sendiri untuk mengukur dan menentukan garis pangkal masing-masing dan selanjutnya menentukan batas-batas maritime selanjutnya. Negaranegara pantai harus memasukkan ketentuan 
dasar hukum laut internasional ini dalam perundang-undangan negaranya agar tercipta suatu keseimbangan kepentingan maritim antara negara pantai dengan komunitas internasional lainnya.

Perubahan Iklim Sebagai Penyebab Perubahan Fisik Garis Pangkal

Konvensi Kerangka kerja PBB tentang Perubahan Iklim (United Nations Framework Convention on the Climate Change/UNFCCC) mendefinisikan perubahan iklim sebagai perubahan dari iklim yang berkaitan langsung atau tidak langsung dengan aktivitas manusia yang mengubah komposisi atmosfer global, yang mana merupakan tambahan dari variabilitas iklim alam, yang diamati selama periode waktu yang sebanding. ${ }^{20}$ Badan Perlindungan Lingkungan Amerika Serikat (United States Environmental Protection Agency/US EPA) mempublikasikan inti dari penyebab perubahan iklim, baik faktor alam maupun faktor manusia yang merubah iklim bumi. Dilaporkan bahwa sebelum adanya manusia, perubahan iklim terjadi sebagai sepenuhnya hasil alam seperti perubahan orbit bumi, perubahan dalam aktivitas matahari, atau erupsi gunung berapi. Sejak era industri dimulai, manusia telah menyebabkan meningkatnya sebab iklim, terutama dengan bertambahnya miliaran ton gas rumah kaca yg terperangkap dalam atmosfer. Sebagian besar pemanasan yang diamati, terjadi sejak pertengahan abad ke20, yang disebabkan emisi gas rumah kaca oleh manusia. ${ }^{21}$ Namun, melalui pemantauan bertahun-tahun, iklim secara afirmasi berubah dan kegiatan manusia merupakan faktor utama yang menyebabkan perubahan ini.

Dampak untuk saat ini dan dampak untuk masa depan di wilayah pesisir akibat adanya perubahan iklim dapat dibagi menjadi tiga kategori: dampak fisik yang berfokus pada fitur pantai dan proses yang mendorong dan dipengaruhi oleh perubahan iklim, dampak ekosistem yang mempertimbangkan efek perubahan iklim pada spesies pesisir pantai yang rentan dan habitatnya, dan dampak sosial yang mempertimbangakan efek perubahan iklim terhadap lingkungan yang telah dibangun manusia.

Perubahan fisik yang terpenting dari lautan yang menyangkut banyak negaranegara pantai atau negara-negara pulau adalah adanya perubahan permukaan air laut yang meningkat seabad ini. Marcus Arcanjo menjabarkan dalam artikelnya bahwa sepanjang abad ke-20, kenaikan air tahunan rata-rata adalah $1,7 \mathrm{~mm}$, namun hal ini meningkat dua kali lipat sejak tahun 1992

20 Pasal 1 United Nations Framework Convention on Climate Change (UNFCC).

21 United States Environmental Protection Agency (EPA) (2017), Causes of Climate Change, diakses pada April, 27, 2015 dari sumber http://www.epa.gov/climate-change-science/causes-climate-change_html 
yaitu mencapai $3,4 \mathrm{~mm} /$ tahun. $^{22}$ Hal ini dapat menjadi suatu kekhawatiran yang memerlukan perhatian internasional secara khusus bagi negara-negara dengan ketinggian daratan yang rendah. Naiknya permukaan air laut dapat membawa konsekuensi bagi negara-negara pantai, terutama pada garis pangkal laut dan pergeseran garis pantai.

Pada sejumlah isu lingkungan internasional, tantangan perubahan iklim ini memerlukan perhatian khusus dari pemerintah negara-negara pantai karena hal ini berkaitan dengan kedaulatan teritorial suatu negara dalam hukum internasional. Kedaulatan teritorial suatu negara, yang meliputi bagian darat, perairan dan udara dapat berkurang akibat naiknya permukaan air laut. Perubahan fisik di garis pantai ini dapat pula mempengaruhi pengaturan hukum laut yaitu UNCLOS 1982.

Respon Rezim UNCLOS 1982 Terhadap Perubahan Fisik Garis Pantai

Terdapat beberapa metode dalam mengukur garis pangkal berdasarkan ketentuan UNCLOS 1982, yaitu melalui garis pangkal biasa, garis pangkal lurus dan garis pangkal lokal khusus. Mengukur lebar laut teritorial melalaui garis pangkal biasa adalah menggunakan garis air rendah sepanjang pantai yang ditandai pada peta skala besar yang secara resmi diakui oleh Negara pantai tersebt, kecuali ditentukan dengan aturan lain dalam UNCLOS $1982 .{ }^{23}$

Ketentuan dalam pasal ini merupakan ketentuan sederhana yang mendefiniskan garis pangkal biasa. Hal ini memberikan dua fakta utama tentang garis pangkal biasa, yaitu garis pangkal diukur nmenggunakan garis air rendah dan peta khusus garis pangkal yang diakui secara resmi oleh suatu negara. Berdasarkan Kantor Urusan Kelautan dan Hukum Laut dari Perserikatan Bangsa Bangsa, garis air rendah adalah persimpangan dari dataran rendah dengan pantai. Sebagian besar grafik kelautan modern sudah tersatndarisasi dengan gelombang astronomi terendah sebagai datum vertikal, sesuai dengan rekomendasi dari Organisasi Hidrografi Internasional (International Hydrographic Organization). ${ }^{24}$ Garis air rendah ini adalah sutau kondisi alam dimana Negara pantai hanya dapat menerima apa adanya dan mengukurnya sebagai suatu batas negara.

Lebih lanjut dijelaskan bahwa Negara pantai biasanya memilih garis air rendah pada grafik yang ada; karena, pertama, kecuali di pesisir pantai dengan kisaran pasang surut lebih besar dari enam meter dan

\footnotetext{
22 Arcanjo, M., (2019), Has Climate Change Rendered the Concept of Sovereign Obselete?, diakses pada Januari, 17, 2019 dari sumber http://climate.org/has-climate-change-rendered-the-concept-of-sovereigntyobsolete/

23 Pasal 5, UNCLOS 1982.

24 Resolutions of the International Hydrographic Organization, Publication M-3, 2nd Edition 2010, Hlm. 54
} 
lapisan es dengan kemiringan rendah yang menuju ke laut, akan ada sedikit perbedaan untuk mengetahui apakah ada atau tidak beberapa daerah beting terpisah yang menjadi elevasi surut. $^{25}$ Kedua, biaya peninjauan daerah lepas pantai untuk suatu datum grafik baru serta persiapan dan penerbitan grafik baru akan memerlukan biaya yang cukup besar. Akan menjadi hal yang sulit untuk membenarkan biaya tambahan peninjauan ini jika grafik yang ada didasarkan pada datum yang tidak sesuai dan menunjukkan garis-garis air rendah dimana terdapat jarak ke arah tanah dari tingkatan yang lebih sesuai. ${ }^{26}$

Bagan garis pangkal dari negara-negara pantai menunjukkan bahwa terjadi pengukuran dan publikasi atas garis pangkal negara-negara pantai tersebut, dan secara alamiah bagan ini menjadi bagan resmi yang diakui oleh negara-negara lain atau pihakpihak lain. Apabila terdapat kasus dimana suatu negara tidak mempublikasikan bagan atau peta pesisir pantainya, maka negara tersebut harus dapat mengadopsi peta negara manapun yang mengambil tugas peninjauan pantainya. ${ }^{27}$ Jika tidak ada bagan yang sesuai, maka negara-negara pantai perlu melakukan peninjauan kembali dan memetakan garis pangkalnya. Lebih lanjut, sebagai solusi jangka panjang, negaranegara pantai perlu menyiapkan dan mencetak bagan garis pangkal khusus yang sesuai dengan skala berdasarkan peta lahan resmi (topografi) yang ada, dan sebisanya merupakan peninjauan yang terbaru. Hal ini menjadi suatu keperluan untuk suatu bagan khusus yang telah dipersiapkan, yang berfungsi menunjukkan garis air rendah dan air tinggi serta semua elevasi air surut. ${ }^{28}$

Tujuan dari bagan khusus ini adalah menyediakan semua informasi yang diperlukan agar pemerintahan negara-negara lain dapat mengetahui dimana titik garis pangkalnya, sehingga otoritas negara lainnya dapat menyebarluaskan informasi bagannya atau dapat menentukan Arah pelayaran dan pemberitahuan khusus bagi pelaut. Direkomendasikan agar daerah tersebut ditandai dengan informasi bahwa tidak dapat digunakan untuk jalur pelayaran. ${ }^{29}$

Garis pangkal lurus dalam Pasal 7 UNCLOS 1982 memperbolehkan negara untuk mengukur luas dari laut teritorial dengan kondisi garis pantai yang sangat menjorok ke dalam dan memotong, atau jika

\footnotetext{
25 Office for Ocean Affairs and the Law of the Sea. 1989. The Law of the Sea Baseline: An Examination of the Relevant Provisions of the United Nations Convention on the Law of the Sea. New York: United Nations, hlm. 25.

${ }^{26}$ Ibid.

${ }^{27}$ Ibid. hlm. 2

${ }^{28}$ Ibid.

29 Ibid.
} 
pinggiran pulau di sepanjang pantai di sekitarnya. Garis pangkal lurus tidak akan ditarik ke dan dari elevasi rendah, kecuali mercusuar atau instalasi permanen serupa yang berada di atas permukaan air laut yang telah dibangun di atasnya atau pengecualian dalam hal di mana penarikan garis pangkal ke dan dari ketinggian tersebut telah menerima pengakuan internasional secara umum. ${ }^{30}$

Pada ketentuan lebih lanjut dalam pasal 7 menyatakan bahwa 'dikarenakan adanya delta dan kondisi alam lainnya, garis pantai menjadi sangat tidak stabil,' yang berarti bahwa UNCLOS 1982 benar-benar mengakui bahwa garis pantai pada garis pangkal lurus dapat berubah karena permukaan air laut. Akan tetapi, ketentuan ini berlanjut dengan 'garis pangkal lurus akan tetap efektif sampai adanya perubahan oleh negara pantai sesuai dengan ketentuan UNCLOS 1982. 'Hal ini memberikan otoritas bagi negara pantai untuk menentukan garis pangkalnya, sesuai dengan Pasal 14 UNCLOS 1982 bahwa 'negara pantai dpaat menentukan .... garis pangkalnya sesuai dengan kondisi alamiahnya sendiri.'

Garis pangkal dalam keadaan khusus seperti mulut sungai (pasal 9), teluk (pasal 10), Pelabuhan (pasal 1), atau bahkan tempat berlabuh di tengah kaut (pasal 12). Dasar pengukuran mulut sungai adalah 'garis lurus yang melintasi mulut sungai antara titik-titik pada garis air rendah pada tepi sungainya' (pasal 9). Seperti halnya teluk (pasal 10), dinyatakan bahwa itu teluk suatu lekukan yang jelas yang lekukannya berbanding sedemikian rupa dengan lebar mulutnya sehingga mengandung perairan yang tertutup dan yang bentuknya lebih dari pada sekedar suatu lingkungan pantai sematamata.

Tetapi suatu lekukan tidak akan dianggap sebagai suau teluk kecuali luas teluk adalah seluas atau lebih luas dari luas setengah lingkaran yang garis tengahnya adalah suatu garis yang ditarik melintasi mulut lekukan tersebut. ${ }^{31}$ Untuk maksud pengukuran, daerah suatu lekukan adalah daerah yang terletak antara garis air rendah sepanjang pantai lekukan itu dan suatu garus yang menghubungkan titik-titik garis air rendah pada pintu masuknya yang alamiah. ${ }^{32}$ Selanjutnya jika jarak antara titik-titik garis air rendah pada pintu masuk alamiah suatu teluk tidak melebihi 24 mil laut, maka garis penutup dapat ditarik antara ke dua garis air rendah tersebut dan perairan yang tertutup karenanya dianggap sebagai perairan pedalaman; ${ }^{33}$ begitu pula apabila melebihi

\footnotetext{
Pasal 7 UNCLOS 1982.

31 Pasal 10 ayat (2) UNCLOS 1982.

32 Pasal 10 ayat (3) UNCLOS 1982.

33 Pasal 10 ayat (4) UNCLOS 1982.
} 
24 mil laut maka garis pangkal lurus yang panjangnya 24 mil laut ditarik dalam teluk tersebut sedemikian rupa, sehingga menurut suatu daerah perairan yang maksimum yang mungkin dicapai oleh garis sepanjang itu. ${ }^{34}$ Pelabuhan juga dapat digunakan untuk membatasi laut teritorial sebagai 'bagian integral dari sistem pelabuhan yang dianggap sebagai bagian dari pantai'.35 Sementara itu, tempat berlabuh di tengah laut (Roadsteads) biasanya diapaki untuk memuat, membongkar dan menambal kapal, dimana terletak seluruhnya atau sebagian di luar batas luar laut teritorial, termasuk dalam laut teritorial. ${ }^{36}$

Perihal lainnya mengenai garis pangkal adalah elevasi surut, yaitu suatu wilayah daratan yang terbentuk secara alamiah ayng dikelilingi dan berada di atas permukaan laut pada waktu air surut, tetapi berada di bawah permukaan laut pada waktu air pasang. Dalam hal suatu elevasi surut terletak seluruhnya atau sebagian pada suat jarak yang tidak melebihi lebar laut teritorial dari daratan utama atau suatu pulau, maka garis air surut pada elevasi demikian dapat digunakan sebagai garis pangkal untuk maksud pengukuran lebar laur teritorial. ${ }^{37}$ Elevasi surut dalam keadaan pasang surut dan terlihat di laut dalam keadaan tenang pada tahap-tahap tertentu dari air pasang, tetapi tidak pada saat pasang naik. Ketika ada elevasi surut yang terjadi secara bersamaan, pihak berwenang dalm suatu negara dapat memproduksi bagan yang menandakan area sebagai pengeringan pada air rendah tanpa harus mengidentifikasi setiap fitur tersendiri yang berdiri di atas permukaan air rendah. ${ }^{38}$

Ketentuan dalam UNCLOS 1982 mengenai garis pangkal tidak memberikan regulasi mengenai perubahan garis pangkal ataupun pergeseran garis pesisir pantai. Tetapi hanya mengatur mengenai bagaimana mengukur dan menentukan garis pangkal tergantung pada kondisi alamiah masingmasing negara pantai. Apabila terdapat suatu perubahan terutama mengenai kondisi naiknya permukaan air laut atau dampaknya pada negara, maka ketentuan tersebut tidak diatur dalam ruang lingkup UNCLOS 1982. Metode pengukuran garis pangkal dari wilayah pesisir pantai umumnya dengan tanda ketinggian air rendah, yang berbeda di antara daerah garis pantai di masing-masing Negara, tergantung pada kondisi alaminya. Ini menunjukkan bahwa tidak ada batas per-

34 Pasal 10 ayat (5) UNCLOS 1982.

35 Pasal 11 UNCLOS 1982.

36 Pasal 12 UNCLOS 1982.

37 Pasal 13 UNCLOS 1982.

38 Office for Ocean Affairs and the Law of the Sea. 1989. The Law of the Sea Baseline: An Examination of the Relevant Provisions of the United Nations Convention on the Law of the Sea. New York: United Nations, Hlm. 2. 
manen yang dapat digunakan untuk menentukan garis pangkal secara mendetail. Dalam ketentuan UNCLOS 1982, tidak ditemukan aturan tegas tentang perpindahan batas dengan garis pangkal. ${ }^{39}$ Dengan naiknya permukaan air laut, elevasi surut akan meningkat sebagai mencairnya lapisan es yang pada akhirnya dapat menggeser titik garis pangkal.

Gambaran umum mengenai pentingnya adanya kondisi penggeseran garis pangkal pada negara pantai dapat dilihat melalui contoh berikut. Pada saat garis air rendah di Samese di Kepulauan Danjo, Perfektur Nagasaki, dikurangi hingga 2 kilometer, maka dapat diestimasi bahwa Zona Ekonomi Eksklusif (ZEE) akan mneyusut sekitar 78 kilometer persegi. ${ }^{40}$ Dalam ruang lingkup ZEE ini, dapat pula menyebabkan kekhawatiran tentang sumber daya yang terkandung dalam ZEE. Hal ini diperkirakan dapat menimbulkan perselisihan internasional, tidak terkecuali dengan zona maritim lainnya. Dengan adanya fenomena perubahan iklim yang perlahan-lahan terjadi, terdapat perubahan bertahap pada garis pantai, dan tidak ada ketentuan secara khusus mengenai hal ini dalam UNCLOS 1982.
Ketentuan yang terdapat dalam UNCLOS 1982 tidak dapat merespon secara efektif terhadap pergeseran-pergeseran yang terjadi pada garis pesisir pantai, yang juga akan berpengaruh pada penentuan garis pangkal laut untuk menentukan dimulainya laut teritorial suatu negara. Rezim perubahan iklim ini dapat memberikan perlindungan terhadap lautan, pulau-pulau rentan, dan ekosistem laut; tetapi ketentuannya berada di luar ruang lingkup UNCLOS 1982 dan instrumen-instrumen yang berkaitan dengannya, yang mana hanya mengatasi dampak-dampak dari perubahan iklim. ${ }^{41}$ Sehingga UNCLOS tidak dapat dikatalan sebagai instrumen internasional yang mampu beradapasi dengan keadaan yang terjadi di bumi saat ini.

Meskipun Negara-negara pantai memiliki hak untuk menentukan garis pangkal untuk menentukan titik dimana pengukuran laut teritorial dimulai, serta berbagai zona lainnya yang didasarkan pada UNCLOS 1982, namun jika garis pangkal laut pada nyatanya mengalami perubahan dan dapat mengurangi luasnya laut teritorial suatu negara pantai, maka hal ini dapat menjadi permasalahan hukum internasional yang baru. Selain menjadi titik tolak dimulainya

39 Redgwell, C., (2012), UNCLOS and Climate Change, American Society of International Law, Vol. 106, Hlm. 408

40 Moritaka, H. (2013), Island's Sea Areas: Effects of a Rising Sea Level, diakses pada April 30, 2015 dari sumber https://www.spf.org/islandstudies/research/a00003.html

41 Redgwell, C., (2012), UNCLOS and Climate Change, American Society of International Law, Vol. 106, hlm. 408 
laut teritorial suat negara pantai, garis pangkal ini juga dapat mempengaruhi luasnya zona ekonomi eksklusif dan landas kontines yang mengandung kekayaan sumber daya alam.

\section{Alternatif Solusi}

a. Publikasi Bagan Garis Pangkal

Mempublikasikan bagan garis pangkal suatu negara pantai menjadi hal yang penting dan mutlak untuk menghindari hilangnya suatu teritorial yang dapat menjadikan area perebutan antar negaranegara pantai. Negara-negara pantai mengalami pengurangan wilayah akibat naiknya permukaan air laut dan menyebabkan sebagian wilayah terendam, sehingga penerbitan batas laut dan zona maritim lainnya serta penetapan batas-batas internasional dapat menjadi kesepakatan dan ketentuan internasional yang bisa diterima oleh semua negara di dunia. Dengan ini, pelanggaran batas-batas maritim negara dan batasan laut lepas dapat terhindari.

b. Protokol tambahan dalam UNLCOS 1982

Meningginya permukaan air laut tidak hanya mempengaruhi Negara-negara pantai, tetapi sangat mempengaruhi negara pulau ataupun negara kepulauan, terutama di daerah samudera pasific. Oleh sebab itu, komunitas internasional harus dapat mendesak pentingnya instrumen internasional tambahan untuk mengatasi hal ini. Ketentuan UNCLOS 1982 merupakan produk kodifikasi hukum internasional tentang laut yang sudah mendapat pengakuan dari hampir seluruh negara di dunia. Perundingan untuk memperbarui UNCLOS 1982 dengan adanya UNCLOS ke empat yang terupdate dengan isu terkini dapat lah menjadi salah satu alternatif. Tetapi melihat penerimaan, pengakuan dan tegakannya ketentuan dalam UNCLOS 1982, perundingan untuk UNCLOS keempat ini dpaat menjadi hal yang sulit. Sehingga adanya protokol tambahan dalam UNLCOS 1982 bisa juga dapat menjadi alternatif yang lebih cepat berlakunya untuk menutupi kelemahan UNCLOS 1982.

c. Perundingan bilateral atau regional Solusi lain yang dapat dilakukan untuk menghindari sengketa internasional mengenai batas laut teritorial dan zona maritim lainnya dari suatu negara adalah dengan mengadakan perundingan bilateral atau regional untuk negaranegara pantai yang berdekatan. Hal ini dapat memperkuat ketentuan hukum yang sudah dibuat oleh UNCLOS 1982.

\section{KESIMPULAN}

Dengan adanya fenomena perubahan iklim yang terjadi di bumi mempengaruhi semua kehidupan manusia. Salah satu 
perubahan fisik yang terlihat dalam kajian hukum internasional terutama hukum laut internasional adalah mengenai naiknya permukaan air laut secara perlahan sehingga dapat menyebabkan adanya pergeseran garis pesisir pantai. Hal ini menandakan bahwa garis pangkal laut yang digunakan sebagai titik acuan dalam mengukur dimulainya laut teritorial seuatu negara sepanjang 12 mil laut juga dapat berubah, karena adanya pergeseran garis pangkal akibat perubahan iklim.

Ketentuan mengenai garis pangkal dalam UNCLOS 1982 nyatanya tidak dapat beradaptasi dengan perubahan fisik garis pangkal. Meskipun UNCLOS 1982 mengakui bahwa garis pangkal adalah sesuatu kondisi alamiah yang sangat tidak stabil dari suatu negara pantai, namun nyatanya UNCLOS 1982 belum dapat menjawab permasalahan mengenai hal ini. Mengingat bahwa bumi yang diisi dengan dua pertiga lautan, serta adanya percepatan pencairan lapisan es di kutub utara dan selatan akibat dari perubahan iklim, maka perundingan internasional untuk mencari instrumen internasional tambahan yang baru perlu dilakukan oleh semua negara-negara pantai serta semua pihak yang berkepentingan mengenai hal ini. Tujuan akhir dari prundingan ini adalah untuk menghindari sengketa internasional tentang batas-batas maritim serta adanya kerangka hukum internasional yang formal.

\section{DAFTAR PUSTAKA}

\section{Buku}

A.V. Lowe, R.R Churchill, The Law of the Sea ( $3^{\text {rd }}$ Eds), (Manchester University Press, 1999)

Redgwell, Catherine, 'UNCLOS and Climate Change' (2012) 106 American Society of International Law

Office for Ocean Affairs and the Law of the Sea. 1989. The Law of the Sea Baseline: An Examination of the Relevant Provisions of the United Nations Convention on the Law of the Sea. New York: United Nations

\section{Jurnal}

Gosling, S.N.; Warren, R.; Arnell, N.W; Good,P. ; Caesar, J.; Bernie, D.; .... Smith, S.M. (2011, Agustus), A review of recent developments in climate change science. Part II: The global-scale impacts of climate change, Progress of Physical Geography, Vol.35, Iss.4

Redgwell, C., (2012), UNCLOS and Climate Change, American Society of International Law, Vol. 106

\section{Peraturan Perundang undangan}

United Nations Convention on the Law of the Sea 1982

United Nations Framework Convention on Climate Change

Resolutions of the International Hydrographic Organization, Publication M-3, 2nd Edition 2010

\section{Internet}

United Nations Division for Ocean Affairs and the Law of the Sea, (2015), Chronological lists of ratification of, accessions and successions to the Convention and the related Agreements, diakses pada April, 28, 2015 
dari http://www.un.org/Depts/los/reference files/chronological lists of ratifications.htm

United States Environmental Protection Agency (EPA) (2017), Causes of Climate Change, diakses pada April, 27, 2015 dari sumber http://www.epa.gov/climate-changescience/causes-climate-change .html

Arcanjo, M., (2019), Has Climate Change Rendered the Concept of Sovereign Obselete?, diakses pada Januari, 17, 2019 dari sumber http://climate.org/hasclimate-change-rendered-the-concept-ofsovereignty-obsolete/.

Moritaka, H. (2013), Island's Sea Areas: Effects of a Rising Sea Level, diakses pada April 30, 2015 dari sumber https://www.spf.org/islandstudies/researc h/a00003.html.
United Nations Division for Ocean Affairs and the Law of the Sea, Ocean and the Law of the Sea, Chronological Lists of Ratification, Accession and Successions to the Convention and the related Agreements as at 3 October 2014, < http://www.un.org/Depts/los/reference_files/chronological_lists_of_ratifications.htm

United Nations Framework Convention on Climate Change, Working Group II: Climate Change Impacts, Adaptation and Vulnerability https://unfccc.int/files/press/backgrounders/application/pdf/press_factsh_science.pdf

United States Environmental Agency (EPA) at http://www.epa.gov. 